\title{
Graptolite fauna indicates the beginning of the Kwangsian Orogeny
}

A research at the State Key Laboratory of Palaeobiology and Stratigraphy, Nanjing Institute of Geology and Palaeontology, has shown, based on a refined division and correlation of the graptolite-bearing strata in southern Jiangxi, China, that the Kwangsian Orogeny commenced in the early Katian Age of the Late Ordovician. Because of its significant research value, this study is published in Volume 53, Issue 11 of SCIENCE CHINA Earth Sciences.

An angular unconformity separating the Lower-Middle Devonian and underlying strata is widespread in the Zhujiang region of South China, and occurs across most of Jiangxi, Hunan, Guangxi and Guangdong provinces. This angular unconformity indicates an orogeny in South China, named by V. K. Ting in 1929 as the Kwangsian Movement, and by T. K. Huang in 1945 as the Chinese 'Caledonian'. The precise age of the orogeny has until now not been well constrained. The present paper identifies the initiation age of the Kwangsian Orogeny, an important event in the geological evolution of South China.

In the Zhujiang region, strata of Cambrian to Silurian age are unconformably overlain by Lower-Middle Devonian rocks. Due to the Kwangsian Orogeny and subsequent tectonic events, the underlying Lower Paleozoic rocks were extensively but gently metamorphosed. Graptolites are the most important index fossils in these metamorphic rocks. Continuous Ordovician sections in Yongxin and Chongyi Counties, south Jiangxi, are widely regarded as type sections for the Zhujiang region. The Lower Ordovician (Tremadocian) to the lower part of the Upper Ordovician (Sandbian) is dominated by black shales (or slates) with a continuous graptolite sequence. In contrast the middle and upper parts of the Upper Ordovician (Katian), namely the Hanjiang, Shikou and Huamianlong Formations, are characterized by thick- to thin-bedded siltstone and sandstone several thousands of meters in total thickness, in which the research recorded only rare graptolites with low diversity.

The Hanjiang Formation contains a Diplacanthograptus caudatus - D. spiniferus graptolite fauna zone of early Katian age. The Shikou and Huamianlong Formations, identified by previous research at separate localities, were in this study lithologically indistinct from the underlying Hanjiang Formation. This re-analysis of graptolite specimens from the Shikou and Huamianlong Formations indicates these are of early Katian Age, and are not representative of the entire Katian as had been ascribed erroneously in previous research due to graptolite misidentifications. Thus, the Shikou and Huamianlong are virtually identical to the Hanjiang Formation, and the researchers suggest their use be abandoned.

There is a sharp facies change from the deep-water black graptolitic shale of the Qixiling and Longxi Formations (Floian to Sandbian) to the thick, coarse, shallow-water near-shore clastics of the Hanjiang Formation (early Katian) which underlies unconformably the Devonian rocks. This facies change, occurring in the early Katian Age of late Ordovician as evidenced by graptolites, indicates the initiation of the Kwangsian Orogeny. This palaeontological and biostratigraphic analysis has played a critical role in resolving the timing of this regional tectonic event, which has puzzled Chinese geologists for decades.

The authors are based at the State Key Laboratory of Palaeobiology and Stratigraphy, Nanjing Institute of Geology and Palaeontology. This laboratory conducts research primarily on five main topics: evolution of early life; palaeozoic biodiversity and environmental change; multidisciplinary stratigraphy and the geologic timescale; the origin and evolution of terrestrial ecosystem; and molecular palaeobiology. This work was supported by funding from the Chinese Academy of Sciences (KZCX2-YW-122, 2008ZX05008-001-001), the Ministry of Science and Technology of China (2006CB806402), and the National Natural Science Foundation of China (40772002).

See the article: Chen X, Zhang Y D, Fan J X, et al. Ordovician graptolite-bearing strata in southern Jiangxi with a special reference to the Kwangsian Orogeny. Sci China Earth Sci, 2010, 53: 1602-1610

Open Access This article is distributed under the terms of the Creative Commons Attribution License which permits any use, distribution, and reproduction in any medium, provided the original author(s) and source are credited. 